\title{
Re-defining co-management to facilitate small-scale fisheries reform: An illustration from northwest Mexico
}

\author{
Elena M. Finkbeiner ${ }^{a, *}$, Xavier Basurto ${ }^{b}$ \\ ${ }^{a}$ Hopkins Marine Station, Stanford University, Pacific Grove, CA, USA \\ ${ }^{\mathrm{b}}$ Nicholas School of the Environment, Duke University, Beaufort, NC, USA
}

\section{A R T I C L E I N F O}

\section{Article history:}

Received 11 July 2014

Received in revised form

8 October 2014

Accepted 10 October 2014

\section{Keywords:}

Small-scale fisheries

Governance

Multi-level

Co-management

Northwest Mexico

\begin{abstract}
A B S T R A C T
Small-scale fisheries face a suite of multi-level challenges, making the reliance on centralized governance approaches and self-governance alone unlikely to lead to long enduring solutions. Although co-management has been long proposed as a promising institutional arrangement, co-management can take many forms; thus, not any type of co-management will be effective for the suite of challenges facing small-scale fisheries today. This paper argues for moving beyond traditional conceptualizations of comanagement, to 'multi-level co-management,' in order to explicitly emphasize the principles of power devolution based on subsidiarity, cooperative partnerships, democratic participatory involvement, polycentricity, and governance networks. The experience of Northwest Mexico is used to illustrate the potential, opportunities, and barriers in achieving multi-level co-management in an effort to contribute to the constructive dialogue developing around the world, and in the region, on small-scale fisheries governance reform.
\end{abstract}

(c) 2014 Published by Elsevier Ltd.

\section{Introduction}

Over 50 million men and women are directly employed by global fisheries and the vast majority are characterized as "small-scale" or artisanal [1-3]. Small-scale fisheries (SSF) function outside of highly specialized industrial fleets and exploit multiple fisheries using a diversity of gear types. Despite the fact that SSF are a critical source of livelihoods $20 \%$ of the world's fishers earn less than one dollar per day [4] and many of the world's marine ecosystems, including nearshore coastal ecosystems, are declining due to overfishing $[5,6]$. SSF managers and practitioners are constantly faced with governance challenges given multi-faceted and sometimes conflicting objectives such as economic efficiency, livelihood and food security, and ecological sustainability. As a result certain policy prescriptions can cause simultaneous successes and failures [7], and policies implemented without proper consideration of local institutional and ecological context, and the linkages across these system components, may result in unintended consequences [8]. Furthermore fisheries agencies in developing countries often lack the monetary, personnel, and political resources for adequate implementation and enforcement $[1,9]$, pointing to the inadequacy

\footnotetext{
* Corresponding author.

E-mail address: elenamf@stanford.edu (E.M. Finkbeiner).
}

of centralized approaches to SSF governance and to the need of more involvement of local stakeholders.

Increasingly co-management, "a hybrid regime combining centralized and decentralized, state and community institutions" [10], is promoted as a viable governance alternative capable of addressing the shortcomings associated with governing from a single institutional level alone [10-12]. However, co-management as a general broadly defined term is not sufficiently insightful to guide policy-making. This paper argues for moving beyond traditional conceptualizations of comanagement, to "multi-level co-management," in order to explicitly emphasize the principles of power devolution [13], cooperative partnerships [14], democratic participatory involvement [15], polycentricity [16], governance networks [17], and subsidiarity (Table 1) [15]. Given small-scale fisheries' history of marginalization and alienation from policy processes, this paper argues for a particular form of comanagement that can better attend to important barriers for achieving more productive social and ecological governance outcomes.

Co-management can manifest in various ways, and its complexities are sometimes ignored [17]. Instead of existing as an exact blueprint prescription, scholars have suggested co-management as a continuous spectrum of governance arrangements from almost entirely state governance to almost entirely user group governance $[14,18]$. Furthermore co-management arrangements often constitute more than just a state-community relationship, and neither the state nor communities are homogeneous structures [17]. Increasingly it is conceptualized as a governance network with 
Table 1

Key concepts of multi-level co-management.

\author{
Cooperative partnership \\ Devolution of governance power \\ Principle of subsidiarity \\ Democratic participatory involvement \\ Polycentricity \\ Co-management as a network
}

Users and government are equal partners [14]

Legislative transfer of authority from national to local governments [13]

Suggests that decisions affecting interests should be made at lowest levels of organization with functional institutions [15,21]

All those affected should be involved in a deliberative decision-making process $[15,67]$

Multiple centers of decision-making, at different levels function in a coherent manner with consistent and predictable patterns of interacting behavior [16]

Web of agreements and relations linking public sector to private sector, with explicit acknowledgement of heterogeneity within each sector [17]

Table 2

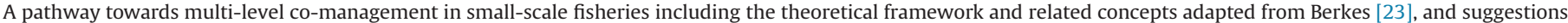
for bridging theory to practice in the case of Mexican small-scale fisheries and elsewhere.

Communicative action: Reaching a shared understanding and vision through a locally-controlled, deliberative process Self-organization: Developing relationships and the emergence of networks
and organization

Collective action: Creating new rules-in-use or institution building, in addition to capacity building for those involved in shared governance
Involve all stakeholders, particularly marginalized interests like illegal fishers Create a space for multiple narratives at the table

Pay explicit attention to power dynamics so powerful interests do not capture the process Through social learning achieve a shared understanding among all interests

Creation and support of vertical and horizontal networks

Leverage existing latent networks of cooperative federations

Leverage histories of corporatist and cooperative culture

Institution and capacity building at local and federal levels of governance emphasizing simultaneous government commitment and local accountability

Creation and reinforcement of enabling conditions to 1) legitimize the right to organize at the local level and 2) providing assistance and services to support local institutions Principle of subsidiarity to guide devolution of governance power

Devolution of power to local levels contingent upon functional institutions, accountability and transparency

Leverage support from policy communities for capacity and institution building

Co-production of knowledge to guide iterative process and facilitate social learning varying interactions among the state, communities, NGOs and other public interests, as well as companies and private interests [17,19]. And finally, co-management does not necessarily imply "government" as sometimes interactions are amongst informal levels of governance [17].

Regardless of the exact governance arrangement, co-management almost always implies that some governance tasks (i.e. decisionmaking, enforcement, monitoring, conflict-resolution) are decentralized to non-state actors. Decentralization processes can take many forms [13], each suitable for different contexts [15] and subsequently producing disparate outcomes. For instance, deconcentration involves the transfer of authority from the national government departments to regional and field offices of national government. Delegation implies the passing of some authority to local officials while the central government still has power to overturn local decisions. The legislative transfer of authority from national to local governments is characterized as devolution. And finally, privatization involves the transfer of responsibility to non-governmental organizations, community associations and private entities [13]. Based on the principles of democracy and subsidiarity, scholars have suggested that different governance powers and rights should be decentralized (or not), so that all affected interests are involved in decision making, and that these decisions are made at the lowest levels of organization, respectively $[15,20,21]$. While community participation has been found to be an important institutional criterion in fisheries co-management [20], decentralization and participatory involvement are not necessarily synonymous [15].

When governance power is effectively devolved to user groups or other interested parties, creating cooperative partnerships and participatory involvement, co-management may resemble V. Ostrom and colleagues' [16] definition of a polycentric system, in which multiple centers of decision-making at different levels function in a coherent manner with consistent and predictable patterns of interacting behavior [16]. Proponents of nested polycentric systems have argued that a nested governance system is more likely to support sustainability and resilience of the resource it governs when decision-making is not centralized. Under this perspective a nested polycentric system can be superior to other governance regimes by potentiating the advantages of centralized and fully self-governing regimes. On the one hand, through the involvement of resource users, local knowledge can inform the design of diverse context-specific rules. On the other hand, larger organizations (including but not limited to government) can enhance local capacity to deal with non-contributors or local corruption, share and invest in information, and coordinate cross-boundary problems [22].

In principle, co-management is an attractive alternative when state control or self-governance alone is not sufficient for resource governance. But fostering cross-scale coordination and a redistribution of power from the government to local collective and/or private stakeholders can be extremely difficult [23], especially given histories of mistrust between the state and fishers [11]. State agencies are often recalcitrant and unwilling to give up political power [12,13] for diverse reasons, including abdication of their responsibility to represent society's interests as a whole. Similar to other governance configurations, co-management can result in unintended consequences - often the usurpation of political power by private or special interests [10]. Berkes [23] succinctly summarizes these important gaps between theory and practice of decentralization, and suggests a pathway forward in light of these challenges, combining communicative action, self-organization, and collective action in a dynamic, iterative process (Table 2).

The purpose of this paper is to outline the potential and barriers to developing multi-level co-management processes as part of small-scale fisheries reform. These arguments are illustrated through the experience of Northwest Mexico small-scale fisheries. First the paper provides an overview of small-scale fisheries in northwest Mexico (i.e., Baja California and the Gulf of California) 


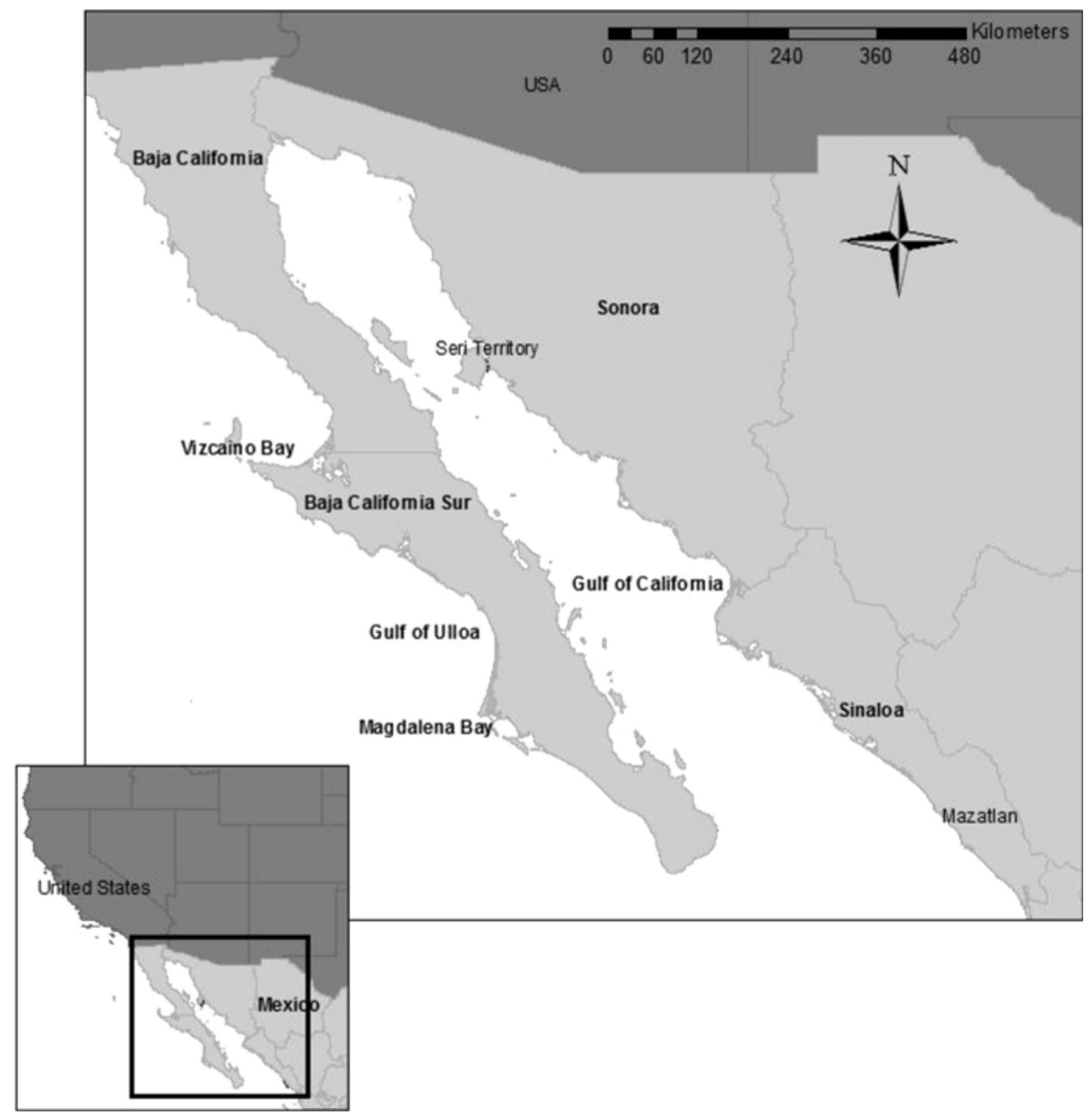

Fig. 1. Map of Northwest Mexico with relevant features.

and describes, through a brief consideration of past policies, the historical context under which isolated examples of comanagement have emerged in this region. Next the paper elucidates, through examination of an example of a multi-level comanaged fishery in Northwest Mexico, factors affecting the emergence of this governance system in a broader context, including reflections on the barriers and challenges. The paper concludes by outlining a pathway towards small-scale fisheries reform through multi-level co-management applicable to Mexico and beyond.

\section{Small-scale fisheries in Northwest Mexico}

Northwest Mexico provides a representative example of characteristics, phenomena, and challenges affecting effective governance of small-scale fisheries worldwide. Marine resource extraction is of primary economic and cultural importance along the coast of Northwest Mexico (Fig. 1) [24,25] with nodes of high and low impact tourism and urban development. Small-scale fishing activities are characterized by a high degree of diversity of targeted catch and fishing gear [26-28]. Over 75 different species groups are exploited in a single port in Magdalena Bay alone, including benthic and pelagic bonyfishes, elasmobranchs, mollusks, crustaceans, and other marine invertebrates (Fig. 1) [27]. The variety of fishing gear includes traps, hook and line, gillnets, artisanal longline, artisanal shrimp trawls, jigging, and hookah diving [26].

Due to the region's high diversity and productivity of marine resources and importance of small-scale fishing, many communities along Baja's peninsula have experienced immigration from other regions in Mexico [29]. Resettlement in Baja was encouraged and incentivized by the federal government starting in the 1970s, following the decline of mainland fisheries [29]. Additionally, ephemeral, seasonal fishing camps are common in the region [30,31]. In this context defining a typical fishing "community" in Northwestern Mexico quickly becomes challenging, as socio-economic characteristics tend to be highly variable across sites. Fishing communities show an uneven distribution of fisheries rights, and over time fisheries rights have tended to accumulate under wealthier and more powerful individuals in control of the commercialization channels, i.e., fish-buyers. Fisheries rights consolidation seems to have further exacerbated socio-economic disparities in the region and incentivized unsustainable fishing behavior [32-34].

Northwest Mexico fisheries are subject to spatial and temporal fluctuations in productivity and biological production due to El Niño 
Southern Oscillation-driven inter-annual changes in oceanographic conditions [35,36]. Due to this variability in the ocean environment, many fishers in the region distribute their risk by engaging in a variety of fisheries using different gear types, traveling to various locations and having multiple livelihood activities. Changing biophysical conditions are not the only source of uncertainty; strong connections with international markets, and a high degree of volatility in local market prices, render fisheries vulnerable to market fluctuations. Other exogenous and endogenous forces have also contributed in recent years to variability and uncertainty affecting small-scale fishing activities, such as the recent economic crisis of 2008, increased conflict in Mexico associated with the narcotic trade, a subsequent halt in tourism, and changing oceanographic conditions such as seasonal reductions in dissolved oxygen and $\mathrm{pH}$, among others [37].

Diverse market dynamics link these fisheries locally, nationally, and globally despite the fact that fishing operations occur in very discrete environments using small outboard motor fiberglass vessels $(\sim 8 \mathrm{~m})$, often with no more than a three-person crew. When species are commercialized, their distribution reaches local, national, and global markets. This variation depends on a range of cultural norms and monetary values associated with different targeted marine resources. Species that have marginal or no market value are consumed within the household, re-distributed to other members of the community (i.e., widows, elderly, etc.), or kept as bait. Typically various species of finfish, mollusks, sharks, and rays are consumed locally and regionally, while species like lobster, abalone, geoduck clams, shrimp and shark fin often have direct ties to international markets.

In sum, the dynamic nature of these fisheries poses significant governance hurdles to overcome. With constant changes in catch composition due to strong seasonality and inter-annual shifts in species availability, the demographic, spatial, and temporal changes in fishing "communities," and rapidly fluctuating markets at different scales, the dynamism of these fisheries adds a great deal of complexity for governance. This difficulty in governance is exacerbated by limited resources for scientific monitoring, policy-making, and enforcement. As in the case of many SSF throughout the world, effective governance must address food security and livelihoods in addition to ecological sustainability and economic efficiency. Thus Mexican agencies are faced with a particularly arduous task of balancing management objectives and trade-offs given resource constraints in the face of the highly dynamic, complex, and diffuse nature of small-scale fisheries, rendering centralized governance efforts more likely to be inefficient and ineffective in achieving on-the-ground governance objectives. Authors have cited high costs of generating relevant fisheries data, a general disregard for, and exclusion of, fishers during policy-making processes, low central government capacity for enforcement, and corruption, as factors associated with de facto open-access conditions in the region $[29,32,38-40]$.

Commencing in the 1980s, and gaining momentum in the 1990s, the transformation towards neoliberalism - a political ideology supporting economic liberalization, privatization, free trade, open markets, and deregulation - dominated as a concerted effort by the state to address governance shortcomings in resource extraction economies. Neoliberal policies, intended to bolster foreign investment opportunities and export markets, simultaneously advocated changes in the Mexican constitution undermining the foundation of communal property rights and collective governance [38]. According to Young [29], attempts to increase foreign investment and access to export markets had the effect of exacerbating resource depletion and de facto open access conditions. Overall, the literature on contemporary Mexican fisheries governance often points to the central government's failure to prevent the demise of coastal and marine resources [29,32,38,40-43].

At the same time, attempts by fishers themselves to self-govern their behavior and safe-guard their resources have often not been enough to deal with external drivers prevalent in the region, such as the encroachment of outside fishers, climate driven disturbances, or market volatility. For example, in some documented cases, selfgovernance, informal rule setting, and de facto no fishing reserves declared by fishers themselves were not enough to stifle unsustainable and illegal fishing practices [44]. Without legal backing and support of these informal governance regimes, and supplementary enforcement provided by the federal government, communities are often unable to successfully keep roving bandits and other illegal fishing activity at bay, and are forced to abandon their communal contracts [44,45]. The difficulty of governing Mexico's marine resources from just one institutional level provides a powerful impetus for moving towards a multi-level co-management regime as an alternative to address current governance shortcomings.

Some of the benefits subscribed to polycentric or multi-level co-management regimes by their proponents seem to be quite well-suited for the Mexican fisheries context, and are listed below: First, allowing fishers to partake in decision-making processes can aid in the creation of flexible, locally appropriate rules, allowing fishers to adapt in the face of change $[11,46]$. Fostering adaptive co-management regimes is particularly important given increasing variability and uncertainty these regional fisheries face [37], as well as for other social-ecological systems characterized by complexity, uncertainty and non-linearity [47]. Second, because fishers are tightly coupled to fisheries resources, they have access to high quality and low cost information regarding their fishery resource [10]. The co-production of ecosystem knowledge is important for increasing our rate of learning of highly complex systems $[23,46,48]$. Similarly, given high transaction costs of fisheries (information, decision-making, operational, and monitoring and enforcement costs; see [49]), fisheries governance can be achieved at lower costs when these duties are shared [10,17]. Third, if fishers are included in the decision making process, formal regulations may be increasingly viewed as legitimate and fair by fishers, subsequently increasing compliance and social equity $[10,11,48-51]$. Previous research in Northwest Mexico has shown that fishers are willing to invest in resource improvement and enforcement, yet the current system has created disincentives, precluding this from happening [40]. Finally a shift in management power, in terms of shared duties and responsibilities, can better take advantage of existing incentives. For example, federal agents have limited incentives to follow through on responsible management of revenue-poor, small-scale fisheries given their duties and responsibilities to monitor and enforce industrial fishing regimes. Meanwhile incentives for proper management by small-scale fishers themselves are much higher, as their livelihoods are dependent on the state of the fishery. For example, various fisher organizations from the region have themselves established no fishing reserves [37,44,52]. But as discussed above, without formalized recognition of locally-devised governance efforts, it is unlikely fishers' attempts at resource stewardship can be long-lived. This is particularly true in a highly integrated setting, where catch production and distribution is linked across local, national, and international scales.

\section{A multi-level co-management case study: Vizcaino cooperatives}

To date, nine fishing cooperatives from the Vizcaino region of Baja California Sur (BCS; Fig. 1) have participated in multi-level comanagement. These cooperatives were granted long-term concessions from the federal government to extract spiny lobster and abalone, and have emerged as highly organized fisheries-the first small-scale fishery in Latin America to be recognized by the Marine Stewardship Council [53]. The Vizcaino cooperatives 
adhere to stringent informal rules devised by fishers themselves, have implemented no fishing marine reserves, actively participate in scientific monitoring and the creation of fisheries legislation, have helped to establish sanctions for illegal harvesting, maintain highly effective internal rotating enforcement bodies, and exhibit strong vertical integration in the global market [37,52,54]. The nine Vizcaino cooperatives are incorporated at a higher level by the FEDECOOP, a federation providing processing, marketing, scientific evaluation, coordination, and interest representation to all nine member cooperatives [52]. For these particular cooperatives, the impetus to move towards multi-level co-management seemed to be catalyzed by several important enabling conditions.

First the mutual trust between local resource users and authorities from the federal fisheries agency has evolved over many years in the region, commencing in times of resource scarcity and crisis in their lobster and abalone fisheries [54]. Realizing that they did not have the necessary resources to adequately assess the status of the valuable but depleted lobster and abalone populations along the Vizcaino coast of Baja, the federal fisheries agency entered into an agreement with fishing cooperatives of the region: fishers would actively partake in collecting fisheries data, alongside government scientists, that would feed into decision-making processes and advise annual catch limits. In exchange for their active participation in stock evaluations, cooperatives were eligible to receive place-based, exclusive access to these resources for 20-year periods, with the potential for renewal. This trust among scientists, fishers, and the central government emerged slowly after decades of collaboration in the state of BCS [54].

Second the Mexican Constitution contains an important clause, which enabled informal co-management arrangements to materialize in BCS even before fisheries co-management legislation was in place. The Code for Civil Procedure (El Código de Procedimientos Civiles) states that voluntary agreements between or among parties must be considered contractual [54]. As such in the early 2000s, informal fisheries "sub-committees" emerged in every municipality of BCS, convening constituents from municipal, state, and federal governance levels, and giving local resource users more clout in decision-making processes [54]. With the help of this constitutional clause, interactions among fishers and various levels of government in informal "sub-committees" fostered the emergence of a multi-level co-management regime.

Third, Vizcaino cooperatives' rights to their most lucrative resources-abalone and lobster-are mediated through concessions, in place of the more commonly issued fishing permits. Concessions are a much stronger form of property-right to fishing, issued by the government to the cooperative every 20 years, with exclusive place-based delimitations for the capture of particular species. While fishing permits authorize access and withdrawal rights to a particular resource, concessions also authorize the right to exclude others from extracting the resource within the spatial jurisdiction granted to each cooperative (see [55]). Given their right to exclude outside fishers from harvesting lobster and abalone resources within their respective concessions, many of these cooperatives have found incentives to develop highly organized internal enforcement bodies [52]. Furthermore, the possession of an exclusive access concession may provide incentives to make improvements to, and self-govern, fishing resources. This is evident in their crafting of stringent informal rules to safeguard lobster and abalone populations, the declaration of no fishing reserves within their concession boundaries, and their participation in scientific monitoring and in the creation of fisheries legislation [37,52]. In sum, the Vizcaino cooperatives enjoy much stronger access, withdrawal, management, and exclusion rights [55] than do other cooperatives of BCS. In this context the distribution of governance power is more equitable across users and government agencies than elsewhere, approaching the most idealized conception of co-management - cooperative, whereby resource users and government share equal governance power (Table 1) [11,14,54].

Importantly, there is considerable variation in the relative governance success of cooperatives with concessions for lobster and abalone along the Pacific coast of Baja. Cooperatives further south of the Vizcaino region (i.e., Gulf of Ulloa and Magdalena Bay; Fig. 1) tend to be less isolated and more vulnerable to poaching. In this context, self-governance and internal enforcement of concession boundaries becomes difficult and fishers within these cooperatives face incentives to break their own rules. In sum, while concessions have provided an important platform for building comanagement regimes, concessions alone do not guarantee sustainable resource use or constructive fisher-government interactions; other factors may come into play, including shifting demographics, local politics, access to markets, and proximity to urban areas.

\section{Opportunities and challenges for the expansion of multi- level co-management}

Given the critical need for better cross-scale coordination between fishers and authorities, what is the potential for scaling-up a multi-level co-management process across smallscale fisheries in Mexico beyond the Vizcaino case? Mexico has started to create certain political opportunities for small-scale fisheries reform through decentralization. Yet at the same time, significant challenges lay ahead before multi-level co-management processes can take hold more broadly. Next, recent opportunities and relevant challenges for the expansion of a multi-level co-management process across small-scale fisheries in Mexico are summarized below.

\subsection{Laying the groundwork to increase opportunities for multi-level co-management}

Recent governance initiatives in Mexico provide tangible examples of efforts to lay the groundwork for multi-level co-management beyond BCS fishing cooperatives. In 2001 the federal fisheries commission (CONAPESCA) office was moved from Mexico city to Mazatlan, Sinaloa, in an effort to bring decision-making processes directly to the regions affected by these decisions (Fig. 1) [43]. Then, in 2007, an important legislation was passed in the General Law of Sustainable Fishing (La Ley General de Pesca y Acuacultura Sustentable), setting the stage for re-allocating governance power among federal, state, and municipal bodies on matters including permit and license application, the development of fisheries management plans, and in monitoring and enforcement [54,56]. The 2007 General Law of Sustainable Fishing became an important legal platform for the creation of formal state and municipal level fisheries councils, intended to represent local and regional interests in decision-making processes, and the National Fisheries Council, intended to provide support, coordination, and continuity across governance levels and sectors [54]. Although the state of BCS had already instituted informal fisheries "sub-committees" at the municipal level in the early 2000s, the 2007 law provided legal backing for the existing sub-committees [54].

The multi-level co-management process developed between Vizcaino cooperatives and municipal, state, and federal levels of governance after decades of collaboration is, nonetheless, a rare example across Mexican fisheries [56]. Scholars have suggested that the failure to redistribute power in fisheries governance has occurred due to several factors. First the State Fisheries Councils, while promising as mechanisms to increase fishing stakeholder 
participation in decision making processes, are at an early phase of development and political support $[43,56]$. Second, permitting and licensing still occurs only in federal offices and state offices act only as a point of interception for license applications [56]. This form of decentralization, referred to as delegation, involves the passing of some authority to local officials; however, the central government still retains the power to overturn local decisions and take power back at any time [13]. Third, movement of federal fisheries offices to Mazatlan from Mexico city in 2001 is yet to translate into decentralized decision-making power and not only a change in geographic location [43]. Sometimes referred to as administrative decentralization, or deconcentration [13], the transfer of authority from national government offices to regional or field offices of the national government is not the same thing as the devolution of authority to other governance levels. While existing laws may have effectively deconcentrated and delegated governance power the devolution, or the legislative transfer of autonomous authority and power from the central government to regional and local governments [13], has not yet occurred in Mexican fisheries. As such co-management in the majority of fisheries in Northwest Mexico can be characterized as consultative, whereby mechanisms exist for governments to consult with users, but essentially all decisions are still made, in large part, by the federal government [14].

\subsection{Challenges for expansion of multi-level co-management}

Vizcaino cooperatives are exceptional in Mexico as they can find incentives to benefit from their exclusive access to highly valued species like lobster and abalone. The pay-off from proper governance of these lucrative species is relatively large, and their benthic nature facilitates ease of governance. The Vizcaino cooperatives' remote location buffers these fisheries from the threat of outside poaching. Such behavior characteristic of Vizcaino fishers may not occur in other contexts where social-ecological conditions are not as conducive to collective action and cooperation with government agencies. For example, many small-scale shrimp fisheries around Northwest Mexico have to compete for the same stock as that of large industrial fleets $[38,41]$. Shrimp stocks have been in decline for decades, and furthermore the availability of domestically farmed shrimp has driven the price down (Finkbeiner, unpublished data). In cases like this full decentralization of governance power may never come to fruition, nor may it even be appropriate. Higher levels of governance are critical to coordinate cross-scale interactions present in fisheries like shrimp. However small-scale shrimp fishers have historically been alienated from policy processes [38], so there is considerable opportunity to increase small-scale fisher representation and participation in governance.

A history of mistrust and disenfranchisement among different small-scale fisheries stakeholders can be a rate-limiting step for co-management functionality [11]. In rural Mexican fishing communities, a previous lack of government presence and involvement can reduce trust and generate animosity between fishers and external agents. Other factors have further alienated fishers from governance processes with implications for generating trust. For example the tendency for many permits to accumulate in the hands of few powerful people has created a labor force of fishers who do not possess the legal right to fish on their own, and thus have virtually no political capital or influence in policy processes [40]. As property-rights have been identified as an important component of co-management [48] if the majority of small-scale fishers in Mexico continue to fish without legal rights, this could undermine any attempt at scaling up co-management. Not only are these fishers disenfranchised from policy-making, but information regarding new laws often does not reach fishers effectively [40]. A severe lack of communication and involvement was evidenced in 2012 when a new law regarding a seasonal closure of sharks was published online in the Federal Register a day before the shark ban went into effect. This took many fishers by surprise at the onset of the shark fishing season when fixed costs had already been invested in the fishery. Mistrust between fishers and the government has also been engendered by decades of corruption within environmental and fisheries agencies as meager government salaries are often augmented by bribes to ignore illegal fishing activity [29,38]. Finally, while trust is important for co-management, if the transition towards co-management is not executed carefully with proper consideration of existing informal and formal governance regimes, established trust and social capital could be compromised [57]. The generation of trust is a pre-condition, an ongoing process, and a desired outcome of co-management and will take patience and effort to achieve.

The transition towards co-management could also be undermined by the difficulty in changing institutional pathways due to path dependency and resulting robust and rigid institutions; systemic shifts do not happen overnight but are long, dynamic processes. Path dependency and robust institutions are particularly relevant concepts for Mexico where a single political party - the Institutional Revolutionary Party (PRI) - remained in control for 71 years. Lessons learned from Chile's transformation towards fisheries co-management suggests that such a governance transformation takes several decades of trial and error even after enabling legislation was put into place [58]. And generating and strengthening a stewardship ethic may take even longer after the governance transformation [59]. Available evidence from the indigenous Seri fisheries in Sonora (Fig. 1) suggested that informal rule/enforcement regimes could take nearly a decade to emerge after formal property rights were granted to fishers [33], as can the generation of trust and a working relationship between government and fishers [54]. As dynamic processes, political interactions, and outcomes are never fixed, accumulated trust and social capital could be eroded at any time [47]. Iterative cycles of conflict and cooperation among organizing citizens and recalcitrant authoritarians characterize Mexico's political process, alternating between the generation and repression of social capital [60]. In sum, if Mexican political history can serve as a guide, governance transformation in Mexico will likely not be an abrupt, monotonic or static phenomenon, but rather take time to manifest, and involve multiple iterations and failures.

Recent empirical research evaluating the performance of fisheries co-management regimes around the world has found local leadership and social capital to be important predictors of successful co-management, and suggests that "additional resources should be spent on efforts to identify community leaders and build social capital" [61]. While the importance of these concepts is undeniable, more attention should be paid to power asymmetries at local and regional levels when leaders are identified, public process is encouraged, and social capital is fostered [18,47]. Mansuri and Rao [62] caution the "naïve application" of complex concepts, such as participation and social capital while ignoring issues of power, class, wealth, ethnicity, and gender. If these dynamics are not adequately considered in the transition towards co-management, people in power can influence and perhaps capture the process and exacerbate existing inequalities $[18,62]$. While some scholars consider socio-economic heterogeneity important for organization at the community level (as those with greater assets can afford to incur the costs of collective action, i.e., [63]), socio-economic heterogeneity also increases the risk of capture, rent-seeking behavior, and collusion by local elites $[10,62]$. For example, Cinner et al. [64] found that while co-management can benefit small-scale fishing communities and ecosystems, benefits tend to accrue in the hands of wealthier resource users. Likewise Gelcich et al. [65] found that the dominant discourse in policy arenas on comanagement is usually propagated by those in power who are 
benefitting from the process, and effectively masks alternate discourses on issues of inequity and access.

Evidence suggests that local capture of economic rent and policy process is pervasive in rural Mexico when efforts to decentralize development funds resulted in capture by state and municipal elites, possibly for political gain, and did not accomplish broader societal goals like poverty alleviation [66]. Looking across Mexico's small-scale fisheries sector, if not carefully considered, interactions between permit holders and fishers can lead to increased disenfranchisement of fishers and fishing rights with important implications for biodiversity conservation [34]. Close attention must be paid to existing power asymmetries resulting from different forms of fisher organization [34] if governance rights are devolved to the state or municipal level in Mexico or if communities are encouraged to become more involved in participatory processes. Similarly, efforts to encourage local leadership and social capital development must not be carried out haphazardly.

\section{Pathway towards multi-level co-management}

While the above barriers pose significant challenges to transitioning towards multi-level co-management, they do not entirely preclude the possibility of a progressive emergence of effective cross-coordination and governance power devolution in Mexico. Berkes [23], for instance has highlighted the importance of focusing on three processes intended to bridge the gap between theory and practice and aid in the transition towards a comanagement regime. Here we describe them in the context of multi-level co-management illustrating the degree to which they are already present in Mexico. The three phases or processes are communicative action, self-organization, and collective action (Table 2) (i.e., [23]). These processes are not mutually exclusive or linear; they may happen simultaneously or iteratively.

Communicative action involves reaching a shared understanding of relevant issues and the creation of a shared vision through a locally-controlled, deliberative process (Table 2) [15,23]. This is an important step in transitioning towards multi-level co-management as perceptions, needs, and goals vary across fishers and fishing communities and between fishers and the government. Participatory involvement emphasizing deliberative processes is also important for social learning [67], a proposed key component of successful co-management processes [19]. Social learning occurs when "parties learn to redefine situations in terms of what they can achieve collaboratively" [19]. As decentralization does not necessarily imply participatory involvement, attempts at multi-level co-management should ensure that these processes occur simultaneously. In a communicative and collaborative process, issues such as - who is participating, how the process is structured, how knowledge is used, how agreements are reached, and how conflicts are resolved - all need to be addressed explicitly [48].

In particular, fostering a democratic participatory process should include adequate consideration of power dynamics. Individuals who are more empowered are more secure to represent their interests and vision in a public process, while others may face economic or social consequences for their involvement [62]. Inevitably there will be winners and losers in such a participatory process; therefore stakeholders with more power must be receptive to minorities' concerns, and willing to compromise to reach a unified understanding [18]. For example, in the case of Mexican small-scale fisheries a considerable proportion of the fishing labor force does not posses own permits or fishing rights; as such these fishers are rooted in a history of marginalization and lack any sort of political clout [32]. However difficult, in a truly democratic process [15], these fishers interests should be represented during the communicative action phase. Importantly, there must be space where multiple narratives can be presented, considered, and combined into a shared understanding or unified voice [15].

By definition, co-management involves the decentralization of power. Thus empowerment is critical in this process, especially within the communicative action phase. Importantly, sharing governance power does not necessarily imply a zero-sum game where power is increased at the local scale by reducing power at another scale [68]. Rather, power can be created through empowerment processes at the individual and collective levels [68]. Mexico's revolution and subsequent land tenure reform were predicated on the concept of empowerment and governance at the local scale by the resource users. Although neoliberal movements have since weakened the culture and practice of communal resource users governance, this historical inertia could help in creating a unified understanding and vision of shared governance power between fishers and the government.

The process of self-organization involves the development of relationships and the emergence of networks and organization (Table 2) [23]. Some authors have argued that during this phase, the creation and reinforcement of horizontal and vertical networks is critical. In Chile the transition towards fisheries co-management was facilitated by a shadow (latent) network of fisher confederations that had been suppressed previously, but re-emerged during the transformation process and facilitated cross-scale coordination [58]. Mexico is also in a unique position to take advantage of realized and latent networks during a self-organization phase. Historically, Mexico's revolutionary reform created incentives for collective action and social capital formation through incentives and subsidies in the agrarian and small-scale fisheries sectors [60]. For example, until recently, permits for the most important commercial small-scale fisheries were distributed only to groups of fishers formally organized as cooperatives (although informally, some cooperatives did not necessarily function "cooperatively" as resources and rights were guarded by individuals in a position of power). While these permits can now be legally distributed to individuals, the formation and maintenance of fishing cooperatives is still encouraged by specific financing initiatives reserved only for cooperatives. Each of these fishing cooperatives is organized at higher levels through cooperative federations (similar to the Chilean case) that aid in organization and interest representation. These strong horizontal and vertical networks constitute the foundation of a polycentric system, and can be leveraged during the self-organization phase to bridge various levels of governance and facilitate coordination.

Collective action is the third phase proposed by Berkes [23] critical for the transition towards co-management reform (Table 2). This phase is characterized by new rules-in-use or institution building, in addition to capacity building for those involved in shared governance [23]. Institutional and capacity building is necessary at both government and resource user levels for multi-level co-management to be effective, as there is a simultaneous need for government commitment and accountability of local leaders [62]. The establishment of "enabling legislation" is an important precondition for institution and capacity building for co-management success $[13,69]$. Enabling legislation must involve authorizing and legitimizing the right to organize to support the creation and enforcement of institutional arrangements at the local level $[13,70,71]$. Enabling legislation is also critical for the provision of assistance and services (administrative, technical, and financial) supporting the sustainability and longevity of local institutions [13]. Mexico has already implemented important enabling policy for the creation of co-management institutions, but more needs to be done to effectively devolve power to state and municipal agencies by granting sufficient legal status and governance authority. For this to occur functional institutions capable of carrying out governance tasks at the local level must already be established, and appropriate 
mechanisms must be in place to ensure accountability and transparency in local leaders. In the case of Mexico, and many other countries, corruption at the local level poses a significant hurdle for accommodating attempts at decentralization. Other developing countries have successfully addressed issues of corruption in the fisheries sector by convening diverse committees, with built in accountability mechanisms, when making decisions about licensing, etc. and by disclosing information regarding public process and licensing to the general public [72]. Finally, while multi-level comanagement emphasizes the devolution of governance tasks to the lowest level of organization affected by decisions, not all tasks are appropriate to devolve, especially in the case of multi-sectoral fisheries (i.e. shrimp). In these cases, it may be necessary for the central government to continue to contribute to enforcement, monitoring, and conflict-resolution mechanisms. However, at the very least, small-scale fishers' interests need to be represented adequately and justly during decision-making processes.

In recent years, fishers in Northwest Mexico have become more involved in capacity building, participatory processes, and empowerment processes $[73,74]$. These processes have often been prompted or supported by numerous international, regional, and local NGOs and foundations, with a shared collective interest in researching and supporting sustainable interactions between human communities and the local marine environment [75]. While most of the normative inclinations of these actors are decidedly "environmental," their presence as "epistemic policy communities" [76] or stakeholders with a shared understanding and interest seem to be increasingly pivotal to connect local issues with regional, national or international agencies and foster governance transitions in the region [75]. Resources and support from non-governmental organizations could be particularly important during participatory processes, and in developing capacity and accountability in local leaders. As trust between governments and civil society actors through NGOs increases, there will likely be an increased influence from NGOs in the creation and support of polycentric institutions [75] - one of the components of multilevel co-management.

Generation and incorporation of knowledge is an important component of co-management [47], and in the iterative, ongoing processes of institution and capacity building. In the last decade, Mexico has made a concerted effort to increase scientific input in decision-making processes $[56,73]$ and involvement of local users in monitoring and knowledge generation (i.e., the community underwater monitoring group of Kino Bay, Sonora) [76]. Likewise there has been an increase in the number of academic, research, and citizen-based institutions involved in fisheries management research, and current research integrates social and natural sciences better than past approaches to fisheries science [74]. Specifically, development of interdisciplinary research programs and institutions can increase our rate of learning from experiences associated with fisheries co-management [74]. Such holistic research approaches can provide more insight about fisher behavior and motivation given existing environmental and institutional conditions, and resulting interactions and feedbacks with local marine ecosystems [47]. In addition to an increase in scientific research, more legitimacy must be granted to fishers' knowledge. Fishers have a rich and contextual knowledge of the systems they work in, critical for well-adapted policies [23,47,48]. The coproduction of knowledge across fishers and scientists seems to be an effective paradigm for the generation of trust and in the transformation towards cooperative partnerships and multi-level co-management in Mexican fisheries [54].

In sum, implementation of fisheries policies from one institutional level alone may not be adequate for confronting phenomena and processes across scales. For example, top-down fisheries policies in Mexico have tended to disenfranchise fishers, decrease compliance, and incentivize illegal behavior. However, bottom-up governance efforts by fishers themselves have been stifled by their inability to keep outsider fishers away. Isolated transformations towards fisheries multi-level co-management in the last several decades, and recent changes in Mexican fisheries policy, have provided an opportunity to increase communication pathways and trust between authorities and fishers, and ameliorate current governance challenges. Specifically multi-level co-management transformation in Northwest Mexico shows elements of cooperative partnerships, devolution of authority from national to local levels based on the principle of subsidiarity, democratic participatory processes, and polycentric institutions. Yet, despite these comanagement's theoretical promises, there is nothing inevitable about its outcomes [10]. A focus on communicative action, selforganization, and collective action should continue to be a priority for Mexico and other regions interested as it could increase the likelihood towards arriving at more equitable and collaborative fisheries management. As the Northwest Mexico case shows, the simultaneous goals of "downward accountability and upward commitment" [62] can be fostered by leveraging resources from epistemic policy communities. Generation and incorporation of interdisciplinary scientific and local knowledge can play an important role in increasing our rate of learning and designing effective, adaptive co-management institutions. The transition towards sustainable and equitable small-scale fisheries in Mexico and beyond requires simultaneous change from the ground-up and top-down, increased pathways for communication and coordination, and long-term support.

\section{Acknowledgements}

We greatly appreciate the comments and feedback from the journal's anonymous peer reviewer, and we kindly thank Richard Cudney-Bueno for his thoughtful review of this manuscript.

\section{References}

[1] Berkes F, Mahon R, McConney P, Pollnac R, Pomeroy R. Managing small-scale fisheries. Ottawa, Ontario, Canada: International Development Reseach Centre; 2001.

[2] FAO. State of world fisheries and aquaculture. Rome; 2012.

[3] FAO. The state of world fisheries and aquaculture: opportunities and challenges. Rome: 2014.

[4] Béné C, Hersoug B, Allison EH. Not by rent alone: analysing the pro-poor functions of small-scale fisheries in developing countries. Dev Policy Rev 2010;28:325-58. http://dx.doi.org/10.1111/j.1467-7679.2010.00486.x.

[5] Jackson JB, Kirby MX, Berger WH, Bjorndal Ka, Botsford LW, Bourque BJ, et al. Historical overfishing and the recent collapse of coastal ecosystems. Science 2001(293):629-37. http://dx.doi.org/10.1126/science.1059199.

[6] Lotze HK, Lenihan HS, Bourque BJ, Bradbury RH, Cooke RG, Kay MC, et al Depletion, degradation, and recovery potential of estuaries and coastal seas. Science 2006;312:1806-9.

[7] Hilborn R. Defining success in fisheries and conflicts in objectives. Mar Policy 2007;31:153-8. http://dx.doi.org/10.1016/j.marpol.2006.05.014.

[8] Degnbol P, McCay B. Unintended and perverse consequences of ignoring linkages in fisheries systems. ICES J Mar Sci 2007;64:793-7.

[9] Thorpe A, Ibarra AA, Reid C. The new economic model and marine fisheries development in Latin America. World Dev 2000;28:1689-702. http://dx.doi. org/10.1016/S0305-750X(00)00045-0.

[10] Singleton S. Co-operation or capture? The paradox of co-management and community participation in natural resource management and environmenta policy-making Environ Polit 2000;9:1-21.

[11] Jentoft S. Fisheries co-management: delegating government responsibility to fishermen's organizations. Mar Policy 1989;13:137-54.

[12] Jentoft S. Co-management: the way forward. Fish Fish Ser 2003;26:1-16.

[13] Pomeroy RS, Berkes F. Two to tango: the role of government in fisheries. Mar Policy 1997;21:465-80.

[14] Sen S, Nielsen JR. Fisheries co-management: a comparative analysis. Mar Policy 1996;20:405-18.

[15] McCay BJ, Jentoft S. From the bottom up: participatory issues in fisheries management. Soc Nat Resour 1996;9:237-50.

[16] Ostrom V, Tiebout C, Warren R. The organization of government in metropolitan areas: a theoretical inquiry. Am Polit Sci Rev 1961;55:831-42. 
[17] Carlsson L, Berkes F. Co-management: concepts and methodological implications. J Environ Manage 2005;75:65-76. http://dx.doi.org/10.1016/j.jenvman.2004.11.008.

[18] Jentoft S, McCay B. User participation in fisheries management: lessons drawn from international experiences. Mar Policy 1995;19:227-46.

[19] Pinkerton E. Local fisheries co-management: a review of international experiences and their implications for salmon management in British Columbia. Can J Fish Aquat 1994;51:2363-78.

[20] Noble B. Institutional criteria for co-management. Mar Policy 2000;24:69-77.

[21] Marshall G. Nesting, subsidiarity, and community-based environmental governance beyond the local scale. Int J Commons 2008;2:75-97.

[22] Ostrom E. Polycentric systems for coping with collective action and global environmental change. Glob Environ Change 2010;20:550-7. http://dx.doi org/10.1016/j.gloenvcha.2010.07.004

[23] Berkes F. Devolution of environment and resources governance: trends and future. Environ Conserv 2010;37:489-500. http://dx.doi.org/10.1017/S037689291000072X.

[24] Brusca RC, Findley LT, Hastings PA, Hendrickx ME, Torre Cosio J, van de Heiden AM. Macrofaunal diversity in the Gulf of California. In: Cartron JLE, Ceballos G, Felger R, editors. Biodiversity, ecosystems and conservation in northern Mexico. New York: Oxford University Press; 2004. p. 179-203.

[25] Lluch-Cota SE, Aragon-Noriega EA, Arreguin-Sanchez F, Aurioles-Gamboa D, Bautista-Romero JJ, Brusca RC, et al. The Gulf of California: review of ecosystem status and sustainability challenges. Prog Oceanogr 2007;73:1-26.

[26] Cudney-Bueno R, Turk-Boyer PJ Pescando Entre Mareas del Alto Golfo de California: Una Guia Sobre la Pesca Artesanal, Su Gente y Sus Propuestas de Manejo. 1998.

[27] Erisman BE, Paredes Ga, Plomozo-Lugo T, Cota-Nieto JJ, Hastings Pa, AburtoOropeza O. Spatial structure of commercial marine fisheries in Northwest Mexico. ICES J Mar Sci 2011;68:564-71. http://dx.doi.org/10.1093/icesjms/fsq179.

[28] Leslie HM, Basurto X, Nenadovic M, Sievanen L, Aburto-Oropeza MO, CotaNieto JJ, et al. Operationalizing the social-ecological systems framework to assess sustainability, in review.

[29] Young E. State intervention and abuse of the commons: fisheries development in Baja California Sur, Mexico. Ann Assoc Am Geogr 2001;91:283-306.

[30] Cartamil D, Santana-Morales O, Escobedo-Olvera M, Kacev D, Castillo-Geniz L, Graham JB, et al. The artisanal elasmobranch fishery of the Pacific coast of Baja California, Mexico. Fish Res 2011;108:393-403. http://dx.doi.org/10.1016/ i.fishres.2011.01.020.

[31] Ramirez-Amaro SR, Cartamil D, Galvan-Magaña F, Gonzalez-Barba G, Graham $\mathrm{JB}$, Carrera-Fernandez $\mathrm{M}$, et al. The artisanal elasmobranch fishery of the Pacific coast of Baja California Sur, Mexico, management implications. Sci Mar 2013;77:473-87. http://dx.doi.org/10.3989/scimar.03817.05A.

[32] Cinti A, Shaw WW, Cudney-Bueno R, Rojo M. The unintended consequences of formal fisheries policies: social disparities and resource overuse in a major fishing community in the Gulf of California, Mexico. Mar Policy 2009;34:1322-34.

[33] Basurto X, Cinti A, Bourillón L, Rojo M, Torre J, Weaver AH. The emergence of access controls in small-scale fishing commons: a comparative analysis of individual licenses and common property-rights in two Mexican communities. Hum Ecol 2012;40:597-609. http://dx.doi.org/10.1007/s10745-0129508-1.

[34] Basurto X, Bennett A, Weaver AH, Rodriguez-Van Dyck S, Aceves-Bueno JS Cooperative and noncooperative strategies for small-scale fisheries' selfgovernance in the globalization era: implications for conservation. Ecol Soc 2013;18:38

[35] Collins C, Castro C, Asanuma H, Rago TA, Han SK, Durazo R, et al. Changes in the hydrography of central California waters associated with the 1997-98 El Niño. Prog Oceanogr 2002;54:129-47.

[36] Pérez-Brunius P, López M, Pineda J. Hydrographic conditions near the coast of northwestern Baja California: 1997-2004. Cont Shelf Res 2006;26:885-901. http://dx.doi.org/10.1016/j.csr.2006.01.017.

[37] Micheli F, Saenz-Arroyo A, Greenley A, Vazquez L, Espinoza Montes JA, Rossetto $\mathrm{M}$, et al. Evidence that marine reserves enhance resilience to climatic impacts. PLoS One 2012;7:e40832. http://dx.doi.org/10.1371/journal.pone.0040832.

[38] Vasquez-Leon M Neoliberalism, environmentalism, and scientific knowledge: redefining use rights in the Gulf of California fisheries. In: Heyman JM, editor. States and Illegal Practices, Oxford, UK: Berg; 1999.

[39] Cudney-Bueno R, Bourillon L, Saenz-Arroyo A, Torre-Cosio J, Turk-Boyer P, Shaw WW. Governance and effects of marine reserves in the Gulf of California, Mexico. Ocean Coast Manag 2009;52:207-18.

[40] Cinti A, Shaw W, Torre J. Insights from the users to improve fisheries performance: fishers' knowledge and attitudes on fisheries policies in Bahía de Kino, Gulf of California, Mexico. Mar Policy 2010;34:1322-34. http://dx.doi org/10.1016/j.marpol.2010.06.005.

[41] McGoodwin JR. Mexico's marginal inshore Pacific fishing cooperatives. Anthropol Q 1980;53:39-47.

[42] Hastings RM, Fischer DW. Management priorities for Magdalena Bay, Baja California, Mexico. J Coast Conserv 2001;7:193-202. http://dx.doi.org/10.1007/ BF02742481.

[43] OECD. Agriculture and fisheries policies in Mexico. OECD Publishing, Paris, France; 2006

[44] Cudney-Bueno R, Basurto X. Lack of cross-scale linkages reduces robustness of community-based fisheries management. PLoS One 2009;4:e6253.

[45] Berkes F, Hughes TP, Steneck RS, Wilson JA, Bellwood DR, Crona B, et al. Globalization, roving bandits, and marine resources. Science 2006:311:1557-8.

[46] Chapin FS, Carpenter SR, Kofinas GP, Folke C, Abel N, Clark WC, et al. Ecosystem stewardship: sustainability strategies for a rapidly changing planet. Trends Ecol Evol 2010;25:241-9. http://dx.doi.org/10.1016/j.tree.2009.10.008.
[47] Armitage DR, Plummer R, Berkes F, Arthur RI, Charles AT, Davidson-Hunt IJ, et al. Adaptive co-management for social-ecological complexity. Front Ecol Environ 2009;7:95-102. http://dx.doi.org/10.1890/070089.

[48] Jentoft S, McCay BJ, Wilson DC. Social theory and fisheries co-management. Mar Policy 1998;22:423-36. http://dx.doi.org/10.1016/S0308-597X(97)00040-7.

[49] Raakjær Nielsen J. An analytical framework for studying: compliance and legitimacy in fisheries management. Mar Policy 2003;27:425-32. http://dx. doi.org/10.1016/S0308-597X(03)00022-8.

[50] Jentoft S. Legitimacy and disappointment in fisheries management. Mar Policy 2000;24:141-8.

[51] Hauck M. Rethinking small-scale fisheries compliance. Mar Policy 2008;32:635-42. http://dx.doi.org/10.1016/j.marpol.2007.11.004.

[52] McCay BJ, Micheli F, Ponce-Díaz G, Murray G, Shester G, Ramirez-Sanchez S, et al. Cooperatives, concessions, and co-management on the Pacific coast of Mexico. Mar Policy 2014;44:49-59. http://dx.doi.org/10.1016/j.marpol.2013.08.001.

[53] Pérez-Ramírez M, Ponce-Díaz G, Lluch-Cota S. The role of MSC certification in the empowerment of fishing cooperatives in Mexico: the case of red rock lobster co-managed fishery. Ocean Coast Manag 2012;63:24-9. http://dx.doi. org/10.1016/j.ocecoaman.2012.03.009.

[54] Ponce-Díaz G, Weisman W, McCay B. Co-responsabilidad y participación en el manejo de pesquerías en México: lecciones de Baja California Sur. Pesca Y Conserv 2009;1:1-9.

[55] Schlager E, Ostrom E. Property-rights regimes and natural resources: a conceptual analysis. Land Econ 1992;68:249-62.

[56] Ponce-Díaz G, Arregín-Sánchez F, Díaz-de León A, Alvarez Torres P. Promotion and management of marine fisheries in Mexico. In: Winter G, editor. Towards sustainable fisheries law: a comparative analysis. Gland, Switzerland: IUCN; 2009. p. 233-52.

[57] Gelcich S, Edwards-Jones G, Kaiser MJ, Castilla JC. Co-management policy can reduce resilience in traditionally managed marine. Ecosystems 2006;9:951-66. http://dx.doi.org/10.1007/s10021-005-0007-8.

[58] Gelcich S, Hughes TP, Olsson P, Folke C, Defeo O, Fernández $M$, et al Navigating transformations in governance of Chilean marine coastal resources. Proc Natl Acad Sci USA 2010;107:16794-9. http://dx.doi.org/ 10.1073/pnas.1012021107.

[59] Gelcich S, Kaiser MJ, Castilla JC, Edwards-Jones G. Engagement in comanagement of marine benthic resources influences environmental perceptions of artisanal fishers. Environ Conserv 2008;35:36-45. http://dx.doi.org/ 10.1017/S0376892908004475

[60] Fox J. How does civil society thicken? The political construction of social capital in rural Mexico World Dev 1996;24:1089-103. http://dx.doi.org/ 10.1016/0305-750X(96)00025-3.

[61] Gutiérrez NL, Hilborn R, Defeo O. Leadership, social capital and incentives promote successful fisheries. Nature 2011;470:386-9. http://dx.doi.org/ 10.1038 /nature09689.

[62] Mansuri G, Rao V. Community-based and-driven development: a critical review. World Bank Res Obs 2004;19:1-39. http://dx.doi.org/10.1093/wbro/ lkh012.

[63] Baland J-M, Platteau J-P. Halting degradation of natural resources: is there a role for rural communities? Oxford: Oxford University Press and FAO; 1996.

[64] Cinner JE, McClanahan TR, MacNeil MA, Graham NaJ, Daw TM, Mukminin A, et al. Comanagement of coral reef social-ecological systems. Proc Natl Acad Sci USA 2012;109:5219-22. http://dx.doi.org/10.1073/pnas.1121215109.

[65] Gelcich S, Edwards-Jones G, Kaiser MJ, Watson E. Using discourses for policy evaluation: the case of marine common property rights in Chile. Soc Nat Resour 2005;18:377-91. http://dx.doi.org/10.1080/08941920590915279.

[66] Hernández-Trillo F, Jarillo-Rabling B. Is local beautiful? Fiscal decentralization in Mexico World Dev 2008;36:1547-58. http://dx.doi.org/10.1016/j. worlddev.2007.09.008

[67] Marschke M, Sinclair aJ. Learning for sustainability: participatory resource management in Cambodian fishing villages. J Environ Manage 2009;90:206-16. http://dx.doi.org/10.1016/j.jenvman.2007.08.012.

[68] Jentoft S. Fisheries co-management as empowerment. Mar Policy 2005;29:1-7. http://dx.doi.org/10.1016/j.marpol.2004.01.003.

[69] Pomeroy R, Katon B, Harkes I. Conditions affecting the success of fisheries comanagement: lessons from Asia. Mar Policy 2001;25:197-208.

[70] Ostrom E. Governing the commons. New York: Cambridge University Press; 1990.

[71] Ostrom E. Understanding insitutional diversity. Princeton University Press; 2009.

[72] Hanich Q, Tsamenyi M. Managing fisheries and corruption in the Pacific Islands region. Mar Policy 2009;33:386-92. http://dx.doi.org/10.1016/j. marpol.2008.08.006.

[73] Hernandez A, Kempton W. Changes in fisheries management in Mexico: effects of increasing scientific input and public participation. Ocean Coast Manag 2003;46:507-26. http://dx.doi.org/10.1016/S0964-5691(03)00032-2.

[74] Espinoza-Tenorio A, Espejel I, Wolff M. Capacity building to achieve sustainable fisheries management in Mexico. Ocean Coast Manag 2011;54:731-41. http://dx.doi.org/10.1016/j.ocecoaman.2011.07.001.

[75] Espinosa-Romero MJ, Rodriguez LF, Weaver AH, Villanueva-Aznar C, Torre J. The changing role of NGOs in Mexican small-scale fisheries: from environmental conservation to multi-scale governance. Mar Policy 2014;50:290-9. http://dx.doi.org/10.1016/j.marpol.2014.07.005.

[76] COBI. 〈http://cobi.org.mx/programas/regiones/region-de-las-grandes-islas/gru po-de-monitoreo-comunitario-submarino-pescando-datos/>, 2012. 